\title{
Guest Editors' Preface
}

Grammatical gender is known to be prone to language variation and change. The papers in this special issue account for gender variation and change in modern Germanic languages, in particular Danish, German, Norwegian, and Southern Dutch. ${ }^{1}$ With the exception of Danish (common, neuter), all other languages can be characterized as having a three-way gender distinction (feminine, masculine, and neuter). The special issue covers most of what has been discussed in the literature on gender in Germanic (for a recent overview see Kürschner 2020). The most important issues are as follows: simplification, resemanticization, the relationship between gender and other nominal categories, and the pragmatics of gender.

With respect to simplification, Lohndal \& Westergaard discuss Norwegian dialects in which three-way gender systems develop into twoway gender systems. Kühl \& Heegård Petersen demonstrate a tendency for the neuter gender in Danish to be supplanted by the common gender. In contrast to Lohndal \& Westergaard and Kühl \& Heegård Petersen, Auer $\&$ Siegel demonstrate that the three-way gender distinction in German among multiethnic speakers is stable. However, they show that those multiethnic speakers simplify DPs in two ways. First, they use bare nouns and hence omit the (required) article as an item that agrees in gender value with its noun. Second, they use a generalized suffix for prenominal adjectives (that is, schwa) that expresses neither gender nor case, as in standard German.

RESEMANTICIZATION is the process by which highly individuated nouns are increasingly referred to with masculine and feminine pronouns, and lowly individuated ones with the neuter pronoun, regardless of the grammatical gender of the noun. In a multivariate analysis, De Vos et al. show that the most important factor of resemanticization of the pronominal system of Southern Dutch is speech register in informal settings. The tendency for grammatical gender to correspond to natural gender is

\footnotetext{
${ }^{1}$ Most of the papers originate as contributions to a workshop on the Mysteries of Gender at the International Conference on Language Variation in Europe (ICLaVE) 2017. One paper (Gregersen et al., forthcoming) will appear in the next issue of the JGL.
} 
analyzed as a change from below, caused by hampered lexical access to noun gender (gender assignment). Both Kühl \& Heegård Petersen and Auer \& Siegel allude to the process examined by De Vos et al., namely, lexical access.

In this special issue, gender is also addressed in connection with other nominal categories. In the languages discussed, gender is one factor that determines how the paradigms for articles and adjectives are structured. In the Mainland Scandinavian languages, there is a formal distinction between a preposed indefinite and a postposed definite article, where the postposed one is fused with the root into one word. This has given rise to a discussion of whether or not definite articles without attributive adjectives should be seen as two or more declension classes. This issue is taken up by Lohndal \& Westergaard as well as Opsahl.

Finally, the pragmatics of gender is addressed. In the Norwegian speech community at large, the feminine gender is losing ground. In Opsahl's paper, one of the lasting insights is that precisely the one adjective that shows a three-way gender declension in all Norwegian dialects, that is, $\operatorname{liten}(\mathrm{M})-\operatorname{lita}(\mathrm{F})-\operatorname{lite}(\mathrm{N})$ 'small', is used by speakers in its feminine gender value for positioning themselves in interaction, see Cornips 2008. Opsahl demonstrates that the feminine adjective liten, i.e. lita, 'small' may be used to indicate a specific positioning in messages, photographs, and pictures that are posted by individuals on social media. The use of the feminine gender is thus a unique semiotic resource that counteracts the process of gender simplification.

In the following table, we summarize the languages, loci, method(s), types of data, and the approaches for the five papers in this special issue. 


\begin{tabular}{|c|c|c|c|c|c|}
\hline PAPER & Language & Locus & Method(s) & Data set(s) & Approach \\
\hline $\begin{array}{l}\text { Auer \& } \\
\text { Siegel }\end{array}$ & German & \begin{tabular}{|l|} 
articles, \\
adjectives
\end{tabular} & $\begin{array}{l}\text { inferential } \\
\text { statistics }\end{array}$ & $\begin{array}{l}\text { spontaneous } \\
\text { speech }\end{array}$ & \begin{tabular}{|l|} 
variational \\
sociolinguistics
\end{tabular} \\
\hline $\begin{array}{l}\text { De Vos, De } \\
\text { Sutter \& De } \\
\text { Vogelaer } \\
\end{array}$ & $\begin{array}{l}\text { southern } \\
\text { Dutch }\end{array}$ & pronouns & $\begin{array}{l}\text { multivariate } \\
\text { statistics }\end{array}$ & \begin{tabular}{|l|} 
Spoken \\
Dutch \\
Corpus \\
\end{tabular} & $\begin{array}{l}\text { psycho- } \\
\text { and } \\
\text { sociolinguistics } \\
\end{array}$ \\
\hline $\begin{array}{l}\text { Kühl \& } \\
\text { Heegärd } \\
\text { Peterson } \\
\end{array}$ & $\begin{array}{l}\text { Danish in } \\
\text { Argentina }\end{array}$ & \begin{tabular}{|l} 
articles, \\
adjectives
\end{tabular} & $\begin{array}{l}\text { multivariate } \\
\text { statistics }\end{array}$ & $\begin{array}{l}\text { CoSamDa } \\
\text { Corpus }\end{array}$ & $\begin{array}{l}\text { variational } \\
\text { sociolinguistics }\end{array}$ \\
\hline $\begin{array}{l}\text { Lohndal \& } \\
\text { Westergaard }\end{array}$ & Norwegian & $\begin{array}{l}\text { articles, } \\
\text { adjectives }\end{array}$ & $\begin{array}{l}\text { qualitative, } \\
\text { quantitative }\end{array}$ & \begin{tabular}{|l} 
acquisition of \\
Norwegian, \\
Norwegian \\
heritage \\
language \\
\end{tabular} & $\begin{array}{l}\text { generative } \\
\text { acquisition }\end{array}$ \\
\hline Opsahl & Norwegian & $\begin{array}{l}\text { articles, } \\
\text { adjectives }\end{array}$ & qualitative & $\begin{array}{l}\text { NOTA } \\
\text { corpus, } \\
\text { media }\end{array}$ & $\begin{array}{l}\text { third wave } \\
\text { sociolinguistics }\end{array}$ \\
\hline
\end{tabular}

So, what is gender? From a structural point of view, grammatical gender is a composite category selecting the paradigms for articles and adjectives. Gender involves number, highly or lowly individuated nouns, referentiality, animacy, and agency as underlying axes. Therefore, gender assignment and agreement introduce a number of tensions in systems so that gender seems to be prone to inherent variation and change. This makes gender an obvious stumbling block for acquisition and learning, and, as a result, speakers may draw on this semiotic resource to position themselves in ongoing interactions. In this special issue, five different perspectives on gender result in a much fuller picture of how this is done in Germanic languages, namely, Danish, German, Norwegian, and Southern Dutch.

Leonie Cornips, Amsterdam

Frans Gregersen, København 


\section{REFERENCES}

Cornips, Leonie. 2008. Loosing grammatical gender in Dutch: The result of bilingual acquisition and/or an act of identity? International Journal of Bilingualism 12.1-2. 105-124.

Gregersen, Frans, Leonie Cornips, \& Ditte Boeg Thomsen. Forthcoming. The acquisition of grammatical gender of determiners in Danish monolingual and bilingual children: An experimental study. Journal of Germanic Linguistics 33.2 .

Kürschner, Sebastian. 2020. Grammatical gender in Modern Germanic languages. The Cambridge handbook of Germanic linguistics, ed. by Michael T. Putnam \& B. Richard Page, 259-281. Cambridge: Cambridge University Press. 